\title{
WAO-instroom door werkgebonden aandoeningen van de huid en de luchtwegen. Deel II: de luchtwegaandoeningen
}

\author{
A.M. Kremer • S.G. van den Heuvel • K. Jettinghoff • D.J. van Putten
}

Samenvatting Met WAO-instroomgegevens en eindewachttijdgegevens uit 1998-2000 van het Lisv, en gegevens van een vragenlijstonderzoek onder 4.291 werkenden die vanwege een luchtwegaandoening in 1998-2000 een WAO/WAZ-uitkering kregen, of één jaar ziek waren (= WAO-instroom), is onderzoek gedaan naar de WAO-instroom bij 46 gedefinieerde bedrijfstakken, werkgebondenheid van de luchtwegaandoeningen en arbeidsomstandigheden.

Van de 1.563 vragenlijstdeelnemers gaf $37 \%$ aan dat het werk de luchtwegaandoening veroorzaakte. Bij nog eens $21 \%$ verergerde het werk de luchtwegaandoening. Comorbiditeit was bij 51\% mede reden voor het langdurig verzuim. Van de deelnemers werkte $41 \%$.

De gevolgen van een werkgerelateerde luchtwegaandoening kunnen ingrijpend zijn: ruim de helft van de werkenden werkte in een andere functie of beroep en bij een kwart van de niet-werkenden was noodzakelijke aanpassing van werk(omstandigheden) niet mogelijk. Beide aspecten kwamen minder vaak voor bij werknemers met een niet-werkgerelateerde aandoening. Esen complicerende factor bij aanpak van langdurig verzuim vanwege luchtwegproblematiek is de comorbiditeit.

Keywords WAO-instroom, respiratoire aandoeningen, werkgebonden, bedrijfsklassen, epidemiologie

A.M. Kremer $(\square)$

PersonaliaMw. A.M. Kremer, mw. S.G. van den Heuvel en mw. K. Jettinghoff zijn onderzoeker, werkzaam bij TNO

Arbeid;en dhr. D.J. van Putten is daar senior-onderzoeker. CorrespondentieadresMw. dr. A.M. Kremer, arts-

epidemioloog, TNO Arbeid,Postbus 718, 2130 AS Hoofddorp.

E-mailadres: a.kremer@arbeid.tno.nl

\section{Inleiding}

Arbeidsongeschiktheidsstatistieken laten zien dat in 1998-2000 jaarlijks circa 1.650 werkenden vanwege een aandoening van de longen of luchtwegen in de WAO/ WAZ stroomden. ${ }^{1}{ }^{3}$ Gerelateerd aan de totale instroom in de $\mathrm{WAO} / \mathrm{WAZ}$ is dit relatief weinig (circa $2 \%$ ). Luchtwegaandoeningen lijken zich vooral te concentreren in specifieke beroepsgroepen of bedrijfstakken.

In opdracht van het ministerie van SZW heeft TNO Arbeid in 2001 een onderzoek uitgevoerd naar de omvang van de problematiek van werkgebonden huiden luchtwegaandoeningen die leiden tot arbeidsongeschiktheid. ${ }^{4}$ Dit artikel beschrijft enkele resultaten over de luchtwegaandoeningen. Resultaten van de huidaandoeningen zijn beschreven in deel I. ${ }^{5}$ De onderzoeksvragen die aan bod komen, zijn:

1. Wat is de omvang van de instroom in de WAO door werkgebonden aandoeningen van de luchtwegen, en om welke aandoeningen gaat het in het bijzonder?

2. In welke beroepsgroepen/bedrijfstakken treedt de instroom in de WAO door deze aandoeningen op?

3. Welke agentia en werkomstandigheden zijn geassocieerd met werkgebonden luchtwegaandoeningen?

4. Is werkhervatting geassocieerd met de werkgebondenheid van de luchtwegaandoening?

- De belangrijkste risicosectoren voor WAOintrede in verband met luchtwegaandoeningen zijn de rubberindustrie, reinigingsbedrijven, de afbouw in de bouwnijverheid, textielindustrie en de aardewerk/glas/steen/cementindustrie.

- Ruim de helft van de werknemers die vanwege een luchtwegaandoening (exclusief luchtwegkanker) minstens één jaar hebben verzuimd, geeft aan 
dat een andere niet-luchtwegaandoening mede reden is van hun langdurige uitval uit het werk.

- Eén op de 10 werknemers die vanwege een luchtwegaandoening (exclusief luchtwegkanker) langdurig uitvallen, heeft geen beschikking over beschermingsmiddelen voor de ademhaling, terwijl ze wel nodig/gewenst waren, en één op de vijf werknemers verricht regelmatig werkzaamheden in een ruimte die niet wordt geventileerd.

- Verandering van beroep/functie is de belangrijkste 'werkaanpassing' bij werknemers die na langdurig uitval met werkgerelateerde luchtwegaandoeningen weer terugkeren in het arbeidsproces.

\section{Onderzoekspopulatie}

Het onderzoek is als volgt opgezet:

1. Analyse van WAO-instroomgegevens en einde-wachttijdgegevens afkomstig van het toenmalige Landelijk instituut sociale verzekeringen (Lisv). De gegevens hebben betrekking op personen die in 1998, 1999 en 2000 vanwege een luchtwegaandoening recht kregen op een WAO-uitkering, en op personen die in 1999 en 2000 een jaar ziek waren, maar geen recht op uitkering hadden (minder dan 15\% arbeidsongeschikt). Met deze gegevens is de omvang van de einde-ziektejaarpopulatie per bedrijfstak bepaald.

2. Vragenlijstonderzoek onder (ex)werknemers en zelfstandigen met een WAO- respectievelijk WAZ-uitkering, dan wel die één jaar ziek waren vanwege een luchtwegaandoening. Alle personen die in 1998-2000 in aanmerking kwamen voor een WAO-/WAZ-uitkering zijn door de vijf uitvoeringsinstanties (behoren nu tot het UWV) schriftelijk uitgenodigd om mee te doen, met uitzondering van personen:

1. met kanker (CAS-codes R200, R201, R209);

2. met een luchtwegletsel (R500 t/m R599);

3. die zijn overleden;

4. die naar het buitenland zijn vertrokken.

In totaal zijn 4.291 werknemers aangeschreven. Met de vragenlijstgegevens is de werkgebondenheid vastgesteld.

\section{Definities}

Als datum van instroom in de WAO is de datum genomen waarop een persoon 'recht op uitkering' heeft. Deze datum sluit aan op einde eerste ziektejaar.

Verschillende diagnosecodes (CAS-codes) ${ }^{6}$ die gebruikt worden voor de arbeidsongeschiktheidsstatistieken zijn geclusterd in 14 groepen. In de vragenlijst is gevraagd naar de luchtwegaandoening waardoor men arbeidsongeschikt raakte in 13 voorgecodeerde aandoeningen en één open vraag.4 Uitsluiting van kanker en ongevallen levert voor het vragenlijstonderzoek 11 diagnosegroepen op. Verder is nagevraagd of een tweede aandoening/ ziekte een rol speelde bij de arbeidsongeschiktheidsbeoordeling. ${ }^{4}$

Voor de bedrijfsklassenindeling is gebruik gemaakt van bedrijfsgegevens die de uitvoeringsinstanties gebruikten voor hun statistieken. In totaal zijn 46 bedrijfsklassen samengesteld. ${ }^{4,5}$

Werkgebondenheid is vastgesteld aan de hand van de vraag: 'Heeft u de indruk dat de ziekte of aandoening een gevolg is van het werk dat u deed voordat er sprake was van langdurige uitval', met als antwoordmogelijkheden: (1) ja, geheel of grotendeels; (2) ja, voor een belangrijk deel; (3) ja, in beperkte mate; (4) nee, geheel niet. De eerste twee antwoorden zijn gebruikt als indicatie voor de werkgebondenheid van de aandoening. ${ }^{7}$

\section{Analyse}

Om de omvang van de potentiële WAO-instroom te kunnen weergeven zijn twee maten gebruikt:

1. Het percentage van de totale WAOinstroom dat instroomt vanwege een luchtwegaandoening. Dit geeft een indruk van de relatieve omvang van de problematiek.

2. Het aantal personen dat per 1.000 verzekerde werknemers per jaar instroomt in de WAO. Dit geeft een indruk van de risico's op WAO-intrede.

Omdat we geen gegevens hebben over het aantal verzekerden voor de WAZ, zijn de resultaten van het Lisvbestand in dit artikel alleen toegespitst op de WAO.

Per bedrijfsklasse zijn de relatieve risico's (RR) berekend van de WAO-instroom. Als referentie is daarbij het risico van WAOinstroom in alle overige bedrijfstakken aangehouden. Indien het $95 \%$ betrouwbaarheidsinterval de 1,0 niet omvat is er sprake van een statistisch significant verhoogd of verlaagd risico.

Aan de hand van vragenlijstgegevens is door de berekening van 'Adjusted Standardized Residuals' bepaald of het percentage van werkgebondenheid van de afzonderlijke beroepsgroepen en het percentage werknemers dat blootgesteld is aan bepaalde werkomstandigheden statistisch significant afwijken van de rest van de groep. ${ }^{8}$ 


\section{Resultaten}

WAO-instroom ${ }^{1}$ naar diagnose, geslacht en leeftijd

In 1998-2000 bedroeg de totale WAOinstroom 297.734 (exclusief de 16.748 zelfstandigen); van hen stroomden 5.582 in vanwege een luchtwegaandoening. Per 1.000 verzekerden bedroeg de gemiddelde totale WAOinstroom 15,37 werknemers per jaar, waarvan 0,29 met luchtwegaandoeningen. In tabel 1 is de frequentie van de 14 geclusterde diagnosegroepen weergegeven.

De meest voorkomende luchtwegaandoeningen zijn COPD (37,3\%), tumor van de bronchus/long/mesothelioom $(15,7 \%)$ en astma $(10,9 \%)$. Tabel 2 laat zien dat het aandeel van de luchtwegaandoeningen in de totale WAO-instroom bij mannen groter $(2,5 \%)$ is dan bij vrouwen $(1,4 \%)$. Per 1.000 verzekerden is echter de WAO-instroom vanwege luchtwegaandoeningen voor mannen en vrouwen ongeveer gelijk. Bij oudere werknemers is het aandeel van luchtwegaandoeningen in de WAO-instroom ruim tweemaal hoger dan bij jongere werknemers. Wanneer we kijken naar de instroom per 1.000 verzekerden dan lijkt dit leeftijdseffect nog sterker: ouderen stromen vijfmaal vaker dan jongeren de WAO in vanwege een luchtwegaandoening.

\section{Arbeidsongeschiktheid}

Ongeveer de helft (49,8\%) van de werknemers die één jaar ziek zijn geweest, wordt volledig arbeidsongeschikt verklaard. Bij luchtwegaandoeningen is dit percentage hoger $(58,3 \%)$. Passend bij deze bevinding is dat voor werknemers met een luchtwegaandoening de WAO-aanvraag minder vaak wordt afgewezen $(10,9 \%)$ dan voor alle werknemers die één jaar ziek zijn geweest (18,0\%).

Op de peildatum van 1-1-2001 is opnieuw gekeken naar de mate van arbeidsongeschiktheid. Dit is 0 tot 3 jaar na einde ziektejaar van de werknemers.

Tabel 1 Lisv-gegevens: Instroom in de WAO in 1998, 1999 en 2000, inclusief einde wachttijders die niet zijn ingestroomd in 1999 en 2000

\begin{tabular}{|c|c|c|c|}
\hline \multirow[b]{2}{*}{ CAS-code } & \multicolumn{3}{|c|}{ WAO $\mathrm{n}=5.582$} \\
\hline & Aandoeningen van de luchtwegen & $\mathrm{n}$ & $\%$ \\
\hline$\overline{\mathrm{R} 102}$ & Verandering van stem & 79 & $\overline{1,4}$ \\
\hline R200,R201 & Tumor bronchus of long, mesothelioom & 876 & 15,7 \\
\hline R209 & Overige tumoren & 278 & 5,0 \\
\hline $\mathrm{R} 409$ & Tuberculose van ademhalingsstelsel & 52 & 0,9 \\
\hline R500-R509 & Respiratoire letsels & 20 & 0,4 \\
\hline R600, R601, R602, R604 & Infecties bovenste luchtwegen & 237 & 4,2 \\
\hline R603 & Allergische rhinitis & 59 & 1,1 \\
\hline R609 & Overige ziekten bovenste luchtwegen & 98 & 1,8 \\
\hline R610-R619 & Longaandoeningen door externe agentia & 115 & 2,1 \\
\hline R620, R629, R639 & Ziekten pleura en mediastinum & 92 & 1,6 \\
\hline R649, R659 & Acute bronchitis, pneumonie & 206 & 3,7 \\
\hline R660 t/m R669 & COPD & 2.084 & 37,3 \\
\hline R679 & Astma (excl. beroepsastma) & 606 & 10,9 \\
\hline R100, R101, R109, R309, R690, R699 & Overige respiratoire aandoeningen & 780 & 14,0 \\
\hline
\end{tabular}

Tabel 2 Lisv-gegevens: Instroom in de WAO in 1998,1999 en 2000, inclusief einde wachttijders die niet zijn ingestroomd in 1999 en 2000 , uitgesplitst naar leeftijd en geslacht: Percentage van totale instroom en jaarlijkse instroom per 1000 verzekerde werknemers

\begin{tabular}{lrrrrr}
\hline & \multicolumn{2}{c}{ Luchtwegaandoeningen } & \multicolumn{2}{c}{ Totale WAO-instroom } \\
\hline Totaal & aantal & \% van totale instroom & per 1.000 werknemers & aantal & per 1.000 werknemers \\
Geslacht & 5.582 & 1,9 & 0,29 & 297.734 & 15,37 \\
man & & & & & 11,90 \\
vrouw & 3.260 & 2,5 & 0,29 & 132.102 & 20,02 \\
Leeftijd & 2.320 & 1,4 & 0,28 & 165.579 & 163.434 \\
$15-44$ jaar & 1.937 & & 0,14 & 1,46 \\
45 jaar en ouder & 3.645 & 1,2 & 0,71 & 134.284 & 26,27 \\
\hline
\end{tabular}


Tabel 3 Samenvatting van de voornaamste bevindingen over het voorkomen van luchtwegaandoeningen in de bedrijfsklassen

\begin{tabular}{|c|c|c|c|}
\hline Bedrijfsklassen & $\mathrm{RR}$ & $\begin{array}{r}\text { Absoluut } \mathrm{n} \\
=5.582\end{array}$ & Meest opvallende diagnose categorieën (verhoogd WAO-instroom risico) \\
\hline \multicolumn{4}{|l|}{ Risicobedrijfsklassen } \\
\hline Rubber & $3,19 *$ & 14 & COPD $(3,0)$, overige respiratoire aandoeningen $(9,5)^{*}$ \\
\hline Reinigingsbedrijven & $2,71 *$ & 299 & $\begin{array}{l}\text { tumor bronchus/long }(1,7) \text {, tbc }(6,0)^{*} \text {, ziekte bov. lwg }(2,9)^{*} \text {, allergische rhinitis }(6,2)^{*} \text {, } \\
\text { overige ziekten bov. lwg }(2,5) \text {, ziekten pleura/mediastinum }(3,2) \text {, acute bronch/ } \\
\text { pneumonie }(4,4), \operatorname{COPD}(3,0)^{*} \text {, astma }(3,2)^{*} \text {, overige respiratoire aandoeningen }(2,8)^{*}\end{array}$ \\
\hline $\begin{array}{l}\text { Bouwnijverheid: } \\
\text { afbouw }\end{array}$ & $2,08^{*}$ & 64 & bronchus/longtumor $(1,8), \operatorname{COPD}(2,7)^{*}$, astma $(1,7)$ \\
\hline Textiel industrie & $1,97 *$ & 36 & $\operatorname{COPD}(3,1)^{*}$ \\
\hline $\begin{array}{l}\text { Aardewerk/glas/steen/ } \\
\text { cement }\end{array}$ & $1,96^{*}$ & 46 & bronchus/longtumor $(2,9)^{*}, \operatorname{COPD}(2,5)^{*}$ \\
\hline Overheid overig & $1,64^{*}$ & 296 & $\begin{array}{r}\text { overige tumoren }(2,0), \operatorname{COPD}(2,1)^{*}, \text { astma }(1,7) \text { acute bronch/pneumonie }(4,7)^{*}, \\
\text { ziekten pleura/mediastinum }(1,6)\end{array}$ \\
\hline Hout-/borstelindustrie & $1,61 *$ & 69 & tumor bronchus/long $(2,2)$ en overige tumoren $(3,7)^{*}, \operatorname{COPD}(1,6)$ \\
\hline Uitzendbedrijven & $1,52 *$ & 433 & $\begin{array}{r}\text { tbc }(4,2)^{*} \text {, allergische rhinitis }(1,6) \text {, astma }(2,3)^{*}, \operatorname{COPD}(1,5)^{*}, \text { overige respiratoire } \\
\text { aandoeningen }(2,1)^{*}\end{array}$ \\
\hline Voeding/tabak & $1,47 *$ & 119 & tumor bronchus/long $(2,3)^{*}$, overige tumoren $(1,9)$ \\
\hline $\begin{array}{l}\text { Burger- en } \\
\text { utiliteitsbouw }\end{array}$ & $1,31 *$ & 175 & tumor bronchus/long $(1,7)$, longaand. inhalatie $(2,1)$, acute bronch/pneumonie $(3,2)$ \\
\hline $\begin{array}{l}\text { Metaalindustrie/- } \\
\text { nijverheid }\end{array}$ & $1,31 *$ & 450 & longaandoen. inhalatie $(2,5)^{*}$, acute bronch/pneumonie $(1,5)$ \\
\hline \multicolumn{4}{|l|}{$\begin{array}{l}\text { Specifieke } \\
\text { aandoeningen }\end{array}$} \\
\hline Algemeen bestuur & 0,86 & 234 & acute bronch/pneumonie $(6,7)^{*}$, ziekten bov. $\operatorname{lwg}(1,8)$ en overige ziekten bov. $\operatorname{lwg}(1,7)$ \\
\hline $\begin{array}{l}\text { Politie/leger/ } \\
\text { gevangenisbewaking }\end{array}$ & 0,47 & 51 & acute bronch/pneumonie $(4,1)^{*}$ \\
\hline Chemische industrie & 1,33 & 110 & acute bronch/pneumonie $(4,5)^{*}$, tumor bronchus/long $(1,8)$, longaand. inhalatie $(2,9)$ \\
\hline Gezondheidszorg & 0,87 & 472 & acute bronch/pneumonie $(4,6)^{*}$ \\
\hline $\begin{array}{l}\text { Onderwijs/ } \\
\text { wetenschappen }\end{array}$ & 0,89 & 287 & $\begin{array}{r}\text { acute bronchitis/pneumonie }(7,7)^{*} \text {, verandering stem }(19,1)^{*}, \text { ziekten bov. } \operatorname{lwg}(1,8) \text { en } \\
\text { overige ziekten bov. } \operatorname{lwg}(2,2)\end{array}$ \\
\hline $\begin{array}{l}\text { Goederen-/ } \\
\text { personenvervoer }\end{array}$ & 1,20 & 328 & tumor: bronchus/long $(1,7)^{*}$ en overige $(2,0)^{*}$, acute bronch/pneumonie $(2,0)$ \\
\hline Scheepvaart/visserij & 1,26 & 15 & tumor bronchus/long $(3,7)$ \\
\hline Agrarisch bedrijf & 0,70 & 72 & longaandoening door inhalatie $(3,4)$ \\
\hline
\end{tabular}

Op deze datum blijkt dat het percentage werknemers met een luchtwegaandoening dat een uitkering ontvangt, gedaald is van $89,1 \%$ naar $68,2 \%$. Redenen voor deze afname zijn: overleden $(8,8 \%)$, hersteld verklaard $(8,8 \%)$ of andere reden $(3,2 \%)$.

\section{WAO-instroom naar bedrijfsklasse}

Met de Lisv-gegevens is per bedrijfsklasse het relatieve risico (RR) berekend van WAOinstroom door luchtwegaandoeningen. Nagegaan is of sommige luchtwegaandoeningen significant vaker voorkomen bij bepaalde bedrijfsklassen. Tabel 3 geeft een samenvatting.

\section{Zelfgerapporteerde reden voor arbeidsongeschiktheid}

In totaal hebben 1.760 aangeschreven werknemers de vragenlijst ingevuld teruggestuurd (respons $41,0 \%$ ); 21 deelnemers zijn uitgesloten omdat zij kanker hadden (16) of aangaven niet vanwege een luchtwegaandoening een WAO-/WAZ-uitkering te hebben (5).

Deelnemers noemden COPD het vaakst als reden voor arbeidsongeschiktheid $(62,7 \%)$, gevolgd door astma $(28,2 \%)$, acute bronchitis/pneumonie $(28,2 \%)$ en infecties van de bovenste luchtwegen (16,8\%). Bij 60,4\% van de deelnemers gaat het om één aandoening: $33,2 \%$ COPD en $27,3 \%$ om een andere luchtwegaandoening. Een aanzienlijk percentage rapporteerde meer dan één 
Tabel 4 Vragenlijstgegevens: Percentage van gerapporteerde reden(en) van langdurig ziekteverzuim bij werknemers die volgens Lisvgegevens vanwege een luchtwegaandoening in aanmerking kwamen voor een WAO/WAZ-uitkering

\begin{tabular}{|c|c|c|c|c|c|c|c|c|}
\hline \multirow[b]{3}{*}{ Luchtwegaandoening } & \multirow[b]{3}{*}{ Aantal } & \multirow[b]{3}{*}{$(\%) 1$} & \multicolumn{3}{|c|}{ Aantal luchtwegaandoeningen2 } & \multicolumn{3}{|c|}{$\begin{array}{l}\text { Andere gezondheidsreden } \\
\text { speelde rol bij langdurig verzuim?2 }\end{array}$} \\
\hline & & & \multirow[t]{2}{*}{ één $(\%)$} & \multicolumn{2}{|c|}{ meer dan één } & \multirow[b]{2}{*}{$\begin{array}{l}\text { nee } \\
(\%)\end{array}$} & \multirow[b]{2}{*}{$\begin{array}{r}\mathrm{ja} \\
(\%)\end{array}$} & \multirow[b]{2}{*}{$\begin{array}{r}\text { ja, onbekend } \\
\text { welke aandoenin } \mathrm{g} \\
(\%)\end{array}$} \\
\hline & & & & $\begin{array}{r}\text { zonder } \\
\text { COPD } \\
(\%)\end{array}$ & $\begin{array}{r}\text { met } \\
\text { COPD } \\
(\%)\end{array}$ & & & \\
\hline Verandering van stem & 205 & 11,8 & 7,8 & 33,2 & 59,0 & 31,7 & 63,4 & 4,9 \\
\hline $\begin{array}{l}\text { Tuberculose van } \\
\text { ademhalingsstelsel }\end{array}$ & 25 & 1,4 & 40,0 & 32,0 & 28,0 & 48,0 & 52,0 &  \\
\hline $\begin{array}{r}\text { Infecties/overige ziekten } \\
\text { bovenste luchtwegen } 3\end{array}$ & 301 & 17,3 & 16,3 & 27,2 & 56,5 & 34,9 & 60,8 & 4,3 \\
\hline Allergische rhinitis & 209 & 12,0 & 3,8 & 32,1 & 64,1 & 31,6 & 65,1 & 3,3 \\
\hline $\begin{array}{l}\text { Longaandoeningen } \\
\text { door externe agentia }\end{array}$ & 67 & 3,9 & 34,3 & 16,4 & 49,3 & 49,3 & 49,3 & 1,5 \\
\hline $\begin{array}{r}\text { Ziekten pleura/ } \\
\text { mediastinum }\end{array}$ & 68 & 3,9 & 27,9 & 19,1 & 52,9 & 41,2 & 54,4 & 4,4 \\
\hline $\begin{array}{l}\text { Acute bronchitis, } \\
\text { pneumonie }\end{array}$ & 358 & 20,6 & 19,3 & 22,9 & 57,8 & 41,1 & 54,5 & 4,5 \\
\hline COPD & 1.090 & 62,7 & 52,9 & - & 47,1 & 48,7 & 47,9 & 3,3 \\
\hline Astma & 491 & 28,2 & 31,4 & 20,8 & 47,9 & 45,2 & 50,9 & 3,9 \\
\hline $\begin{array}{l}\text { Overige respiratoire } \\
\text { aandoeningen }\end{array}$ & 177 & 10,2 & 71,2 & 11,9 & 16,9 & 54,8 & 39,6 & 5,6 \\
\hline Totaal & 1.739 & 100 & 60,4 & 10,9 & 29,5 & 48,6 & 47,7 & 3,6 \\
\hline
\end{tabular}

1 Percentage van totale onderzoeksgroep $(n=1.739)$ De som is meer dan $100 \%$ omdat deelnemers meer dan één aandoening konden aangeven.

2 Percentage van de groep met een bepaalde luchtwegaandoening. De som is $100 \%$.

3 Overige ziekten bovenste luchtwegen $(n=9)$ gevoegd bij infecties bovenste luchtwegen $(n=292)$.

van de geclusterde diagnosegroepen (39,6\%): 29,5\% inclusief COPD en 10,1\% zonder COPD (tabel 4). Een tweede luchtwegaandoening is relatief vaak aangegeven door deelnemers met allergische rhinitis, een stemverandering, infecties/aandoeningen van de bovenste luchtwegen en met acute bronchitis/ pneumonie. Diagnosegroepen die het vakst als enige reden voorkwamen, zijn COPD, tuberculose en een aandoening uit de categorie overige.

Ruim de helft van de deelnemers $(51,4 \%)$ geeft aan dat een andere niet-luchtwegaandoening mede rede is (geweest) van hun langdurige uitval in het werk. De tweede aandoening betreft vooral een aandoening van het bewegingsapparaat $(23,6 \%)$, psyche $(13,3 \%)$, verhoogde bloeddruk $(8,1 \%)$ en/of hartaandoening $(6,1 \%)$.

\section{Werkgebondenheid van de luchtwegaandoening}

Van de deelnemers uit het vragenlijstonderzoek geeft $37,2 \%$ aan dat de luchtwegaandoening het gevolg is van het werk. Koppelen we dit percentage aan de WAOinstroom per 1.000 verzekerden, dan komt $0,70 \%$ van de totale WAO-instroom voor rekening van volgens werknemers werkgebonden luchtwegaandoeningen. Werkgebondenheid per diagnose(groep) is verschillend (tabel 5). De laagste percentages zien we voor de categorie overige aandoeningen (14,9\%) en ziekte pleura/ mediastinum $(29,0 \%)$ en de hoogste percentages voor allergische rhinitis $(53,1 \%)$ en longaandoening door inhalatie $(70 \%)$. Gemiddeld genomen is het percentage hoger als er sprake is van meer dan één type luchtwegaandoening. Dit laatste gaat echter niet op voor astma en overige aandoeningen.

Van de deelnemers bij wie de luchtwegaandoening niet werkgebonden is, zegt $32,6 \%$ dat deze erger is geworden door het werk. Uitgesplitst naar één of meer luchtwegaandoeningen, blijkt dat dit percentage lager is voor de 627 deelnemers met één type luchtwegaandoening $(27,1 \%)$ dan voor de 338 deelnemers met twee of meer luchtwegaandoeningen $(42,9 \%)$. Dit verschil is voor bijna alle diagnosegroepen aanwezig, met uitzondering voor ziekten/infecties bovenste luchtwegen $(46,7 \%$ respectievelijk $43,3 \%)$ en astma (45,5\% respectievelijk $48,8 \%)$. Voor allergische rhinitis $(n=84)$ is dit 
Tabel 5 Vragenlijstgegevens: Percentage deelnemers dat aangeeft dat hun luchtwegaandoening door het werk veroorzaakt is, uitgesplitst naar type luchtwegaandoening en aanwezigheid van meerdere luchtwegaandoeningen $(\mathrm{n}=1.622)$

\begin{tabular}{|c|c|c|c|c|c|c|}
\hline \multirow[b]{2}{*}{ Luchtwegaandoening } & \multicolumn{2}{|c|}{ Totaal } & \multicolumn{2}{|c|}{ Eén aandoening } & \multicolumn{2}{|c|}{ Twee of meer aandoeningen } \\
\hline & $\mathrm{n}$ & $(\%)$ & $\mathrm{n}$ & $(\%)$ & $\mathrm{n}$ & $(\%)$ \\
\hline Verandering van stem & 190 & 51,6 & 14 & 57,1 & 176 & 51,1 \\
\hline Tuberculose & 22 & 50,0 & 8 & 37,5 & 14 & 57,1 \\
\hline Infecties/overige ziekten bovenste luchtwegen & 287 & 48,4 & 46 & 32,6 & 241 & 51,5 \\
\hline Allergische rhinitis & 196 & 53,1 & 6 & 66,7 & 190 & 52,6 \\
\hline Longaandoeningen door externe agentia & 67 & 70,1 & 23 & 56,5 & 44 & 77,3 \\
\hline Ziekten pleura/mediastinum & 62 & 29,0 & 17 & 23,5 & 45 & 31,1 \\
\hline Acute bronchitis/pneumonie & 334 & 42,5 & 63 & 23,8 & 271 & 46,9 \\
\hline COPD & 1.027 & 36,6 & 546 & 31,3 & 481 & 42,6 \\
\hline Astma & 467 & 46,0 & 148 & 45,9 & 319 & 46,1 \\
\hline Overige respiratoire aandoeningen & 148 & 14,9 & 104 & 18,3 & 44 & 6,8 \\
\hline Totaal & 1.622 & 37,2 & 975 & 32,8 & 647 & 43,9 \\
\hline
\end{tabular}

onderscheid niet te maken, daar op twee na de aandoening in combinatie met andere aandoeningen voorkwam.

Koppelen we arbeidsgebondenheid aan 'luchtwegaandoening erger door het werk' dan blijkt dat voor 58\% van de deelnemers de luchtwegaandoening werkgerelateerd is. Met variantieanalyse is gekeken of werkgebondenheid per beroepsgroep significant afwijkt van de rest. Door de uitsplitsing over grote aantallen beroepen, bleven per beroepsgroep echter weinig deelnemers over. Beroepen die desalniettemin opvallen met een significant verhoogd percentage werkgebondenheid van de luchtwegaandoening zijn wassers/persers $(75 \%)$, walsers/gieters e.d. $(89 \%)$, spinners/wevers e.d. $(80 \%)$, voedingsmiddelen- en drankenbereiders (65\%), loodgieters/ pijpfitters e.d. $(67 \%)$, schilders $(74 \%)$, de groep timmerlieden/metselaars/ bouwvakkers (51\%).

\section{Werkomstandigheden}

In de vragenlijst waren vragen opgenomen naar blootstelling aan agentia en naar werkomstandigheden die belastend (kunnen) zijn voor de gezondheid van longen en luchtwegen. Aan de deelnemers is gevraagd of zij tijdens het werk dat zij deden voordat ze langdurig uitvielen, hieraan (regelmatig) blootgesteld werden. In tabel 6 zijn de percentages vermeld van deelnemers die regelmatig hieraan werden blootgesteld. Er is onderscheid gemaakt naar deelnemers bij wie, naar eigen zeggen, de aandoening veroorzaakt werd door het werk, verergerd werd door het werk en de aandoening niet gerelateerd was aan het werk. Wij hebben getoetst of de vooronderstelling klopt dat bepaalde blootstellingen of werkomstandigheden vaker voorkomen bij deelnemers bij wie de luchtwegaandoening werkgerelateerd is.

Meer dan 50\% van de deelnemers gaf aan dat zij regelmatig werden blootgesteld aan prikkelende stoffen, sigarettenrook, stoffige ruimtes of aan kou/warmte/temperatuurswisselingen. Minstens 50\% van de blootgestelde werknemers kreeg hierdoor ademhalingsklachten. Voor driekwart van de deelnemers was het werk regelmatig lichamelijk inspannend. Tabel 6 laat zien dat de percentages werknemers die te maken hadden met beschreven werkomstandigheden het hoogst waren voor werknemers bij wie de luchtwegaandoening door het werk veroorzaakt werd. De blootstellingpercentages van de degenen bij wie de luchtwegaandoening door het werk verergerde, nemen een tussenpositie in waarbij de percentages vaker neigen naar die van de werkgebonden groep dan naar die van de niet-werkgerelateerde groep. Opvallende percentageverschillen tussen de groepen zien we onder meer bij blootgestelde werknemers voor ademhalingsklachten, contact met stoffen die ook irriterend zijn voor de huid, en slechter ruiken aan einde van de werkdag. Verder werkten deelnemers bij wie de aandoening door het werk werd veroorzaakt vaker in niet-geventileerde ruimtes, en hadden zij vaker geen beschikking over beschermingsmiddelen terwijl ze wel gewenst/nodig waren.

\section{Werksituatie}

Ten tijde van het onderzoek was 40,5\% van de deelnemers (weer) aan het werk. Werk- nemers met een nietwerkgerelateerde aandoening waren vaker aan het werk (47,0\%) dan werknemers bij wie de aandoening veroorzaakt was door het werk $(36,1 \%)$ of verergerd werd door het werk $(35,4 \%)$. Van de werkenden werkte $43,5 \%$ in een andere functie of beroep. Werkenden met een nietwerkgerelateerde luchtwegaandoening waren minder vaak van functie of beroep veranderd $(29,1 \%)$ dan werkenden bij wie de aandoening veroorzaakt was door het werk $(62,5 \%)$ of verergerd was door het werk $(48,0 \%)$. Eén op de vijf niet-werkenden was (mede) niet aan het 
Tabel 6 Percentage deelnemers dat regelmatig was blootgesteld aan bepaalde stoffen of werkomstandigheden: totaal en voor deelnemers bij wie de luchtwegaandoening veroorzaakt werd door het werk (werkgebonden), verergerd werd door het werk en niet gerelateerd is aan het werk $(\mathrm{n}=1.622)$

Blootstelling en werkomstandigheden

Aantal

Prikkelende stoffen (gassen, dampen, rook, vernevelingen, stof, vezels etc)

- nee

- ja, één

- ja, twee-drie

- vier of meer

Indien blootstelling

- Ademhalingsklachten agv blootstelling

- Stof, rook, nevel zichtbaar op werkplek

- Keding onder stof of vochtig

- Direct huidcontact met chemische stoffen/materialen irriterend voor de huid

- Minder goed ruiken aan einde werkdag/werkweek

- Blootstelling aan hoge temperaturen door

productieprocessen

Producten of stof afkomstig van dieren, tuin-/ landbouwproducten

Indien blootstelling

- Hierdoor ademhalingsklachten

- Kleding onder stof einde werkdag

Blootstelling aan sigarettenrook

Indien blootstelling:

- Hierdoor ademhalingsklachten

Blootstelling aan stoffige ruimtes

Indien blootstelling:

- hierdoor ademhalingsklachten

Blootstelling aan kou, warmte en/of temperatuurswisseling

Indien blootstelling:

- Hierdoor ademhalingsklachten

Geen ventilatie van de werkruimte

Regelmatig lichamelijke inspanning

Verricht werkzaamheden waarvoor beschermingsmiddelen nodig/gewenst

- ja, maar niet beschikbaar

- ja, en beschikbaar

Indien beschikbaar:

- geen gebruik

• ja, soms

- ja, regelmatig

• ja, altijd

Tijdens werkdag werkkleding zichtbaar vuil

\section{Totaal}

48,5

15,7

18,6

17,2

62,6

79,4

68,3

42,7

49,4

11,5

52,2

61,3

48,7

52,2

50,0

64,6

67,7

76,6

18,9

76,4

9,8

$\rightarrow, \downarrow$ Percentage is statistisch significant hoger respectievelijk lager ( $\mathrm{p}<0,05$
Veroorzaakt

door het

werk

604

\section{Niet veroorzaakt, maar door het werk wel verergerd}

315

Niet veroorzaakt en niet verergerd door het werk

650

$41,6 \rightarrow$

$20,6 \rightarrow$

$9,1 \downarrow$

$20,0 \rightarrow$

21,3

$10,6 \downarrow$

16,5

$5,1 \downarrow$

64,7

$37,3 \downarrow$

$71,6 \rightarrow$

75,0

$73,2 \downarrow$

$59,8 \downarrow$

$50,6 \downarrow$

$78,2 \rightarrow$

$36,2 \downarrow$

$25,0 \downarrow$

43,5

$23,5 \downarrow$

23,4

$21,1 \downarrow$

$61,1 \rightarrow$

12,1

$5,8 \downarrow$

$17,2 \rightarrow$

52,6

$26,3 \downarrow$

$59,6 \rightarrow$

59,4

$40,6 \downarrow$

69,3

$57,1 \rightarrow$

$44,3 \downarrow$

63,4

$45,1 \downarrow$

$75,4 \rightarrow$

$58,8 \rightarrow$

$28,5 \downarrow$

$82,5 \rightarrow$

$48,0 \downarrow$

$81,0 \rightarrow$

$78,4 \rightarrow$

$50,7 \downarrow$

83,3

$69,4 \downarrow$

18,5

$10,5 \downarrow$

$28,3 \rightarrow$

80,2

$64,2 \downarrow$

$87,3 \rightarrow$

$6,7 \downarrow$

$2,2 \downarrow$

$20,3 \rightarrow$

15,8

$10,9 \downarrow$

$\begin{array}{rrrr}3,3 & 4,9 & 2,2 & 1,6 \\ 15,5 & 17,5 & 11,1 & 14,8 \\ 30,5 & 30,1 & 40,0 & 26,2 \\ 50,7 & 47,6 & 46,7 & 57,4 \\ 52,2 & 73,3 \rightarrow & 55,4 & 31,3 \downarrow\end{array}$

$52,2 \quad 73,3 \rightarrow$

55,4

1,6

14,8

26,2

$31,3 \downarrow$ 
werk omdat er voor hen geen aangepast ander werk was en/of omdat werkaanpassingen of voorzieningen niet mogelijk waren. Deze reden werd het vaakst aangegeven door niet-werkenden bij wie de aandoening door het werk veroorzaakt was $(30,1 \%)$, gevolgd door degenen bij wie de aandoening verergerde door het werk $(19,8 \%)$ en niet-werkgerelateerd was $(9,4 \%)$.

\section{Beschouwing}

Het huidige onderzoek geeft per bedrijfstak een overzicht van het aantal werknemers dat vanwege een luchtwegaandoening één jaar ziek is geweest en aanspraak maakt op een WAO-uitkering (WAO-instroom). Verder geeft het onderzoek inzicht in het voorkomen van werkgebondenheid van deze luchtwegaandoeningen, het voorkomen van comorbiditeit als tweede reden van de WAOinstroom, het voorkomen van voor de luchtwegen belastende werkomstandigheden en de arbeidsparticipatie van deze WAO-instromers.

Er zijn bij dit onderzoek enkele kanttekeningen te plaatsen die van invloed zijn op de resultaten: een geselecteerde populatie bestaande uit werkenden die minstens één jaar verzuimen, misclassificatie van de verzuim-/arbeidsongeschiktheidsdiagnose bij de deelnemers van het vragenlijstonderzoek, verschillen tussen de samenstelling van de populatie van het Lisv-onderzoek en het vragenlijstonderzoek en de kleine aantallen bij verdere detaillering van bijvoorbeeld bedrijfs- en beroepskenmerken. Al deze kanttekeningen zijn kort besproken in de discussie van het eerste deel van het artikel over de huidaandoeningen. 5 De conclusie die wij daaruit trekken is dat gevonden resultaten met betrekking tot werkgebondenheid en comorbiditeit als indicatief beschouwd dienen te worden.

$\mathrm{Bij}$ de resultaten van het vragenlijstonderzoek moet verder rekening gehouden worden met het feit dat die betrekking hebben op arbeidsongeschiktheid vanwege een luchtwegaandoening zonder kanker van de longen en luchtwegen; dit betreft $29 \%$ van de totale instroom vanwege luchtwegaandoeningen. Het is moeilijk aan te geven of en in welke mate inclusie van (ex)kankerpatiënten de totaal percentages over werkgebondenheid, de comorbiditeit en de aanwezigheid van meerdere type luchtwegaandoeningen zou veranderen.

Afgaande op schriftelijke en mondelinge reacties van respondenten zijn er discrepanties tussen de diagnoses in het Lisv-bestand en het vragenlijstonderzoekbestand.4 Verschillende respondenten gaven aan dat men weliswaar een aandoening van de luchtwegen had (of heeft gehad), maar dat de aandoening die leidde tot WAOinstroom een geheel andere was (bijv. COPD met een hartinfarct). Gegeven de forse comorbiditeit is het niet onmogelijk dat de onderliggende diagnose voor WAOinstroom anders is dan de oorspronkelijk geregistreerde luchtwegaandoening. Daarnaast laten de arbeidsongeschiktheidsstatistieken ook niet zien dat meerdere type luchtwegaandoeningen/-klachten (al dan niet als bijkomende klachten of complicaties) een rol kunnen spelen bij het langdurig verzuim van een werknemer (zie tabel 4). Deze mogelijke onvolledigheden van de verzuimregistratiestatistieken kunnen ook een verklaring zijn voor de soms zeer opvallende diagnoses in het Lisv-bestand. Er zijn vrij veel werknemers die met een ogenschijnlijk onschuldige of goed behandelbare aandoening een jaar verzuimen, bijv. zeven gevallen met acute nasofaryngitis4 en de ruim 200 gevallen met acute bronchitis/pneumonie. Dit kan erop wijzen dat bedrijfsartsen een éénmaal opgegeven diagnose niet wijzigen. Deze onvolledigheden in de statistieken kunnen daardoor een overschatting, maar ook een onderschatting geven van de reden van WAOinstroom op CAS-codeniveau, maar ook op het niveau van diagnosegroepen.

Het huidige onderzoek laat zien dat werkomstandigheden bij een aanzienlijk deel van de werkenden die langdurig verzuimen vanwege een luchtwegaandoening, een rol spelen bij het ontstaan of het onderhouden van die luchtwegaandoening. Ruim eenderde is van mening dat de luchtwegaandoening het gevolg is van het werk en eenvijfde geeft aan dat de luchtwegaandoening niet werkgebonden is, maar dat het werk de aandoening wel verergerde. Uit een onderzoek naar WAOinstroom van begin jaren '90 werd een hoger percentage werkgebondenheid gevonden. Gründemann en Nijboer7 vonden aan de hand van dezelfde vraag - een percentage van $47 \%$ voor luchtwegaandoeningen (van de 174 personen). Verschillen in samenstelling van het onderzoeksbestand en ook verschillen in arbeidsomstandigheden kunnen een rol spelen bij dit verschil in onderzoeksresultaat.

Het percentage zelfgerapporteerde werkgebondenheid van de luchtwegaandoeningen kan te hoog zijn. De vraag naar arbeidsgebondenheid is retrospectief gesteld. In de periode van einde ziektejaar en het vragenlijstonderzoek kan men het verleden anders zijn gaan bekijken. Zo konden deelnemers er behoefte aan hebben om de 'oorzaak' van de ziekte bijvoorbeeld bij het werk te leggen. Verder spelen bij het ontstaan van luchtwegaandoeningen meestal meerdere factoren een rol, zoals predispositie en roken. Desondanks laat het onderzoek zien dat werknemers die hun (chronische) luchtwegaandoening aan het werk toeschrijven, vaker blootstelling aan stof, gassen en dampen melden dan werknemers die hun aandoening niet aan het werk toeschrijven.

Voor behoud van werk bij werknemers met een werkgerelateerde luchtwegaandoening, ligt aanpassing van de werkomstandigheden dan ook voor de hand. Deze 
aanpassing kan ingrijpend zijn, zoals dit onderzoek aangeeft. De meerderheid van de werkende deelnemers met een werkgerelateerde luchtwegaandoening is van functie of beroep veranderd. Het onderzoek laat echter ook zien, dat de noodzakelijke (ingrijpende) werkaanpassing in de praktijk niet altijd mogelijk is, en dat dit vaker voorkwam bij de niet-werkende deelnemers met een werkgerelateerde luchtwegaandoening.

Aan de andere kant lijkt werkhervatting van sommige aandoeningen die leiden tot arbeidsongeschiktheid en waarvan de werkgebondenheid vrij snel duidelijk kan zijn, redelijk succesvol. In 1999-2001 meldden bedrijfsartsen 109 gevallen van beroepsastma, 9,10 terwijl slechts 27 personen in 1998-2000 aanspraak maakten op de $\mathrm{WAO} / \mathrm{WAZ}$ vanwege beroepsastma.4

Aandoeningen waarvan de CAS-code een relatie doet vermoeden met het werk, worden niet altijd gemeld bij het NCvB. In 1999-2001 kwamen 40 meldingen binnen van extrinsieke allergische alveolitis (EAA), toxische inhalatiekoorts en stoflongen. Volgens het Lisv waren in 1998-2000 101 werkenden vanwege een pneumoconiose door (an)organisch stof, EAA of vanwege overige longaandoeningen door uitwendige agentia minstens één jaar ziek. Verder meldden bedrijfsartsen slechts 14 gevallen van werkgebonden COPD, ${ }^{9,} 10$ terwijl in het huidige onderzoek ongeveer eenderde van de 2.257 werkenden die vanwege COPD in 1998-2001 de WAO/WAZ instroomden, de aandoening werkgebonden beschouwt. Het NCvB verklaart deze discrepantie door erop te wijzen dat het in individuele gevallen vaak niet goed is vast te stellen in welke mate blootstelling in het werk bijdraagt aan de ontwikkeling van COPD. ${ }^{9}$

Astma en COPD zijn volgens de statistieken verantwoordelijk voor ongeveer de helft van alle langdurige verzuimgevallen vanwege een luchtwegaandoening. Het American Thoracic Society stelt dat bij $15 \%$ van de volwassenen met astma en bij $15 \%$ van de mensen met COPD werkomstandigheden bijdragen aan het ontstaan van de ziekte. ${ }^{11}$ Dit gegeven en het hoge percentage van (subjectieve) werkgerelateerdheid van astma en COPD en van de andere luchtwegaandoeningen die leiden tot langdurige uitval in het werk, geven aan dat bij de sociaal-medische begeleiding van werkenden die langdurig (dreigen te) verzuimen een inventarisatie van werkomstandigheden, beschikbaarheid en gebruik van beschermingsmiddelen op zijn plaats is. In geval van beroepsmatige blootstelling aan voor de luchtwegen belastende blootstellingen mag een werknemer en werkgever van de bedrijfsarts een onderzoek/uitspraak verwachten naar de mate waarin die blootstelling heeft bijgedragen aan de ontwikkeling van de luchtwegaandoening van de werknemer. ${ }^{12}$ Een complicerende factor bij de SMB is de forse comorbiditeit; het voorkómen van langdurige uitval vergt niet zelden een bredere aanpak dan die van het voorkómen van uitval door de gevolgen van de luchtwegaandoening alleen.

\section{Dankwoord}

De auteurs willen hierbij het Nederlands Kenniscentrum Arbeid en Longaandoeningen 'Opgelucht Werken' bedanken voor zijn medewerking aan de uitvoering van het onderzoek en zijn bijdrage aan de ontwikkeling van de vragenlijst.

Belangenconflicten: geen gemeld

Financiële ondersteuning: geen gemeld

\section{Literatuur}

Lisv (Landelijk Instituut Sociale Verzekeringen). Ziektediagnosen bij uitkeringen voor arbeidsongeschiktheid: statistische informatie over medische classificaties in WAO, WAZ en Wajong 1998. Amsterdam: Lisv, 2000.

Lisv (Landelijk Instituut Sociale Verzekeringen). Ziektediagnosen bij uitkeringen voor arbeidsongeschiktheid: statistische informatie over medische classificaties in WAO, WAZ en Wajong 1999. Amsterdam: Lisv, 2001.

Lisv (Landelijk Instituut Sociale Verzekeringen). Ziektediagnosen bij uitkeringen voor arbeidsongeschiktheid: statistische informatie over medische classificaties in WAO, WAZ en Wajong 2000. Amsterdam: Lisv, 2001.

Kremer AM, Heuvel SG van den, Jettinghoff K, Putten DJ van. WAO-instroom door beroepsgebonden aandoeningen van de huid, longen en luchtwegen. Serie Arboconvenanten. Doetichem: Elseviers bedrijfsinformatie bv, 2002.

Kremer AM, Heuvel SG van den, Jettinghoff K, Putten DJ van. WAO-instroom door werkgebonden aandoeningen van de huid en de luchtwegen. Deel I: de huidaandoeningen. Tijdschr Bedrijfs Verzekeringsgeneeskd 2004; 12: 259-266.

Lisv (Landelijk Instituut Sociale Verzekeringen). CAS, Classificaties voor Arbo en SV. Utrecht: Voorlichtingscentrum Sociale Verzekering, 1997.

Gründemann RWM, Nijboer ID. WAO-intrede en werkhervatting. Proefschrift, Universiteit van Amsterdam. Amsterdam: NIA TNO, 1998

Haberman SJ. Analysis of Qualitative Data. Volume 1. Introductory Topics. New York: Academic Press, 1978, p. 111.

NCvB (Nederlands Centrum voor Beroepsziekten). Signaleringsrapport Beroepsziekten 2001. Amsterdam: NCvB, 2002.

NCvB (Nederlands Centrum voor Beroepsziekten). Signaleringsrapport Beroepsziekten 2000. Amsterdam: NCvB, 2001.

Balmes J, Becklake M, Blanc P, et al. American Thoracic Society Statement: Occupational contribution to the burden of airway disease. Am J Respir Crit Care Med 2003; 167: 787-797.

Pal TM, Van Rooy GBJG, Bötger WF, et al. Nederlandse Vereniging voor Arbeids- en Bedrijfsgeneeskunde. Richtlijnen voor bedrijfsartsen: Handelen van de bedrijfsarts bij werknemers met Astma en COPD. Badhoevedorp: EPA van Geer BV, 2003. 